\title{
Vaginal and Other Genital
}

National Cancer Institute

\section{Source}

National Cancer Institute. Vaginal and Other Genital. NCI Thesaurus. Code C13464.

An anatomical qualifier that describes any part of the vagina or female genitalia. 